\title{
Enforceable Community Rights and National Remedies
}

\author{
Andrem Durand ${ }^{*}$
}

\section{Enforceable rights in English law}

In general it has been the existence of a remedy at common law or under statute which has enabled the English lawyer to deduce the existence of a right. EEC law involves the opposite process: it impliedly confers rights which by their nature are ill defined, and leaves it to national law to supply the remedy, a process for which the common law with its limited and distinct categories of civil liability is ill adapted. The European Communities Act 1972 in s.2(1) does not make the process easier. Rights arising under the EEC Treaty are, it is there said, to be recognized and enforced by the courts "accordingly". They are given a name: "enforceable community rights". But the courts are left to work out whether such rights are merely negative: the right to prevent the State (or anyone else) from applying or enforcing inconsistent national law; or restitutionary, the right to get back money illegally levied by the State; or tortious, the right to get damages for infringement of the Treaty.

The appropriate categorization of enforceable community rights is made that much more difficult because two distinct courts are involved, the European Court and the National Court. The remedy and the right, which are the opposite sides of the same coin, are treated as two different coins by two different courts using two different sets of terminology. Nevertheless it has somehow proved workable and gradually the solutions are emerging.

In 1974 Lord Denning M.R. had no doubts as to the appropriate classification of a community right. He concluded, solely on the basis of the European Courts' description of such rights ${ }^{1}$ that in a particular case articles 85 and 86 "create new torts or wrongs. Their names are 'undue restriction of competition within the common market'; and 'abuse of dominant position within the common market'."' He was thereby making two points. Firstly breach of community law was tortious

*Of the School of Law, University of Buckingham.

1. In $B R T$ v. SABAM and others [1974] E.C.R. 313; [1974] 2 C.M.L.R. 238. Note that Denning's expression "Put into English", that judgment shows ...

2. Application des Gaz v. Falks Veritas [1974] 3 All E.R. 51, 58. His certainty disappeared in the Court of Appeal in Garden Cottage Foods v. Milk Marketing Board [1982] 2 C.M.L.R. 584 
conduct and secondly it was tortious by virtue of community law rather than by a virtue of s.2(1) of the European Communities Act 1972. As regards the first point and with reference to articles 85 and 86 Lord Denning's analysis was upheld by a majority of the House of Lords in Garden Cottage Foods Ltd. v. Milk Marketing Board. $^{3}$ The second point was decisively rejected by the House of Lords in that case and by Oliver L. J. in Bourgoin S. A. v. Ministry of Agriculture Fisheries and Food. $^{4}$

The earliest appearance of an enforceable community right in an English court was as a negative right or as "eurodefence" as it is more colloquially called, in which it was not strictly necessary for the court to consider the nature of the right. ${ }^{5}$ A eurodefence can take a number of forms. It can arise in a criminal prosecution in which the defendant whilst admitting the facts denies the offence on the basis of the incompatibility of the offence with the EEC Treaty. ${ }^{6}$ In another form the defendant resists the issue of an injunction on the grounds that the injunction would amount to a measure of equivalent effect to a quantitative restriction prohibited by the Treaty. ${ }^{7}$ In a third form the defendant relies on article $85(2)$ to allege that the contract, the breach of which is the cause of action, is void. In another form the defendant invokes the maxim ex turpi causa non oritur actio to allege that the plaintiff is seeking, by means of his claim, to carry out conduct prohibited by article 85 or $86 .^{8}$

In Garden Cottage Foods v. Milk Marketing Board ${ }^{9}$ the House of Lords for the first time had to consider whether articles 85 and 86 gave an aggrieved party a claim in damages rather than simply a claim to an injunction to restrain the alleged breach of article 86. It decided that it did. ${ }^{10}$ As regards rights derived from other articles of the Treaty and regulations which had been invoked against the government, they have been protected hitherto either by inter partes declaratory

3. [1984] A.C. 130; [1983] 3 C.M.L.R. 43. See further Forrester, [1984] C.M.L. Rev. 11 and Banks [1984] C.M.L. Rev 669 .

4. [1986] 1 C.M.L.R. 267 (CA), at p.295.

5. Supra n.2.

6. Sec for example $R$ v. Tymen [1981] E.C.R 3079, at pp.3094 and 3101. In that case the Advocate-General considered that where Tymen was raising the defence that he could not be convicted of the offence charged under the United Kingdom Sea Fishing Order because the United Kingdom no longer had power to regulate fishing at all, he was raising an issuc of the direct applicability of community law rather than the direct effects doctrine. He was not enforcing a "right" to fish in United Kingdom waters but was denying the applicability of a United Kingdom statutory instrument. If this is an example of the application of the doctrine of direct applicability it is difficult to see why any "eurodefence" should ever raise an issue of direct effect. "Where criminal proceedings are brought by virtue of a national measure which is held to be contrary to community law a conviction in those proceedings is also incompatible with that law," was what the court held. The court declined to consider whether "rights" were conferred on Tymen.

7. Industrie Diensten Groep v. Beele [1982] E.C.R. 707, at p.716.

8. Supra, n.2.

9. [1984] A.C. 130.

10. It left the issue to the trial judge whilst making it clear that in its view damages were available; see An Bord Bainne Co-operative v. Milk Marketing Board [1984] 2 C.M.L.R. 584 (C.A.). 
relief, ${ }^{11}$ by originating summons, ${ }^{12}$ or more frequently by an application for judicial review, ${ }^{13}$ or incidentally in the course of proceedings. ${ }^{14}$ In none of these cases has it proved necessary to consider whether it was a tort to infringe a community provision.

Where the Treaty, regulation, directive or decision is invoked to explain or widen a right granted under municipal law it may not be necessary to consider the nature of the right or the category into which it falls. For example, in the sex discrimination cases the system of remedies in the industrial tribunals had been instituted before the United Kingdom joined the EEC so that it was relatively easy for the tribunals to read the community provisions along with the domestic provisions without posing the question of what category the community rights fell into. The same applies to national insurance cases. The issue would have had to be resolved only in the absence of an appropriate domestic procedure.

For the first time in Bourgoin v. MA.F.F. the issue rose as to whether it was a tort for the Government to break article 30 of the Treaty. This issue will arise whenever the subject is aggrieved and suffers direct damage because of a breach by the State of its obligations under the Treaty or subordinate legislation. It could conceivably arise where the State, in breach of its obligations under a directive, fails to confer a right on one subject which that subject was intended to be able to enforce against another subject. There can be little doubt that in such a situation no right is conferred against the other subject. ${ }^{15}$

In Bourgoin the majority of the Court of Appeal held that a breach by a Member State of article 30 of the Treaty was not a breach of statutory duty sounding in damages, because under English domestic law the Crown was not liable in damages for the wrongful exercise of its legislative powers in the absence of malice and EEC law had not created new causes of action in private law against the State. In his dissenting judgment Oliver L. J. held that the breach by the Ministry of Agriculture Fisheries and Food of its obligations uader article 30 was a breach of statutory duty sounding in damages. All three judges were agreed that the plaintiff had a cause of action against the Crown for the tort of misfeasance in a public office which would require the plaintiff to prove, at the very least, that the minister intended to protect the domestic producer and to damage the plaintiff. Leave to appeal to the House of Lords was granted. ${ }^{16}$

This article advances the proposition that a breach of a directly effective provision of community law by a Member State is a wrong under community law

11. Royal Scholten-Hanig v. Intervention Board [1978] E.C.R. 2037; An Bord Bainne v. Milk Marketing Board [1984] 1 C.M.L.R. 519.

12. MacMahon v. Department of Education of Science and Others [1983] 1 Ch. 227.

13. $R$ v. ILEA, ex parte Hinde and Other [1985] 1 C.M.L.R. 716; $R$ v. Secretay of State for Home Department, ex parte Santillo [1981] Q.B. 778; $R$ v. Allomey-General, ex parte I.C.I. [1987] 1 C.M.L.R. 72.

14. Schorsch Meier v. Hennin [1975] Q.B. 416.

15. Marshall v. Southampton and South West Area Health Authority [1986] 2 W.L.R. 780.

16. The Government apparently agreed a seven figure sum by way of settlement of the claim so that the Court of Appeal judgment is now final. See [1987] I.C.M.L.R. 169; H.C. 1986 C.116. 
and by virtue of community law an aggrieved person has a right to compensation to put him into the position he would have been in, had the wrong not been committed. This right derives from a combination of the article, the breach of which is the substantive cause of the grievance, and article 5 of the Treaty which, it is argued, imposes an obligation on the national courts to award damages where these are appropriate. Although a national court may continue to have a judicial discretion as to whether to grant an injunction or similar order, or to review measures for the purpose of annulling them and to order restitution as a consequence of the annulment, it must, at the very least, place the person to whom a right is granted into the position he would have been in had the right not been infringed. ${ }^{17}$ This article suggests that there is a greater common substantive content to the doctrine of direct effect than that suggested by the majority in Bourgoin. It is only as regards procedure that the national legal system is to some extent autonomous.

\section{The doctrine of direct effect in European Community Law}

The facts of Van Gend en Loos v. Nederlandse Administratie der Belastingen ${ }^{18}$ are well known. On 1 January 1958, the date on which the EEC Treaty entered into force, a particular product was classified under heading 279-a-2 of the Benelux Customs Tariff and was subject to an ad valorem duty of $3 \%$. The structure of that tariff had come about by virtue of the Customs Convention of 5 September 1944 between the Benelux countries which entered into force in 1947. By a protocol concluded between the Benelux countries on 25 July 1958, ratified in the Netherlands by the law of 16 December 1959, the Benelux countries went over to the "Brussels Nomenclature" a standard system of customs classification adopted by the Customs Co-operation Council already used in the EEC Treaty and which was later to become the basis for the Common Customs Tariff of the EEC, the common Agricultural Policy and for trade statistics in general. The new tariff entered into force in all Benelux countries on 1 March 1960. On the date when it entered into force the old 1947 tariff was abolished. The old heading $279-\mathrm{a}-2$ was replaced by a new heading 39.01 but the heading was further subdivided with two different rates of duty. ${ }^{19}$ The result it appears was that the particular product was liable to an ad valorem duty of $8 \%$ whereas previously it had been subject to a duty of $3 \%$.

17. The orthodox understanding of the judgments of the European Court on direct effect is that provided some remedy is available to protect an enforceable community right the classification of the right and the extent of the remedy are matters for national law to determine according to its existing system of remedies. See, for example, John Bridge "Procedural Aspects of Enforcement of E.C. Law", [1984] E.L. Rev. 28. In that article, Professor Bridge urges the adoption of community legislation to mesh the right with the remedy in a more uniform manner: in effect fusion comparable to the fusion of law and equity. In the present author's view many further years of struggle by the national courts and the European Court are necessary before legislative intervention must be resorted to. At the present stage of development legislation might well be regressive.

18. [1963] E.C.R. 1.

19. The four figure heading can be further subdivided ad infinitum by each State which adopts the nomenclature. 
The importer sought the annulment of the decision of the Dutch Customs and Excise charging it a duty of $8 \%$. It did not, let it be stressed, seek anything as far fetched as the annulment of the Benelux tariff or of the law ratifying that tariff. If it had put forward such an argument the Customs and Excise tribunal, before which the dispute was brought, would undoubtedly have declared itself incompetent and would have dismissed the importers appeal as inadmissible and conceivably the doctrine of direct effect would never have entered the legal world. Instead it asked the Tariefcommissie to quash the individual customs decision, a task well within that tribunal's ordinary statutory competence. The ground for its appeal was that "all the customs duties applied by Member States in their trade with each other were bound on 1 January 1958" by virtue of article 12 of the EEC Treaty.

The concept of "bound" duties derives from the General Agreement on Tariffs and Trade. ${ }^{20} \mathrm{~A}$ national court must "set aside the application of customs duties introduced or increased in breach of its provisions". The revolutionary nature of the importer's argument was concealed behind its use of conventional tariff concepts. Although Article 12 provides quite clearly that "Member States shall refrain from increasing the customs duties which they already apply in their trade with each other"18 it was entirely silent on any legal consequences as regards importers of the breach of that article.

The Dutch court referred two questions to the European court, the first of which was to have a profound impact on community law. It asked "whether article 12 of the EEC Treaty has direct application within the territory of a Member State, in other words, whether nationals of such a State can, on the basis of the Article in question, lay claim to individual rights which the courts must protect."21

In its observations before the Court the Dutch Government drew the now well recognized distinction between (a) the internal effect of article 12 and (b) its direct effect. ${ }^{22}$ Internal effect depended on the intentions of the contracting parties. Was the Treaty intended to be law creating? This is the concept which we have come to describe as "Direct Applicability". ${ }^{23}$ Even if the obligation on the Netherlands was an obligation to be recognized as part of municipal law (which the Netherlands denied) it would not necessarily have direct effect, in other words confer "subjective rights". This distinction is clearly known to all legal systems. For example, an Act of Parliament in the United Kingdom is clearly law creating: it has an "internal effect" in the terminology of the Netherlands Government. But there is a wholly distinct question as to whether a provision in an Act of Parliament

20. Article 11 of the GATT in conjunction with the schedule of concessions; see Amminstrazione Delle Finance Dello Stato v, SPI and SAMI [1983] E.C.R. 801. In this judgment the court explains the system of GATT bindings. Note that the far more precise provisions of the GATT are found not to confer rights on individuals.

21. Emphasis added.

22. J. A. Winter, 9 C.M.L. Rev. 1927.

23. In the early days of the development of the Community doctrine the expression "self-executing" was often used, particularly by Roemer, Advocate-General. 
creates individual rights. A power and duty conferred and imposed on a statutory body by an Act of Parliament is of course law. It can be enforced in the United Kingdom by the appropriate minister or the Attorney-General. It does not follow, however, that it can be enforced $b y$ an individual; still less that it can give rise to a private right in damages. The duty imposed on the Netherlands by article 12, even if recognized as part of the Netherlands law, would not necessarily mean that Van Gend en Loos could obtain the annulment of its customs assessments or restitution of over-paid duty.

As regards the second aspect the Dutch Government recognized what a positive answer would mean. "It would put in issue the responsibility of States by means of a procedure which was not designed for this purpose." As early as 1962, therefore, the Dutch Government realised that what was really at issue was whether breach of article 12 was a wrong for which a State would be liable.

The Belgian Government approached the second issue of the effect of article 12 within the State within more traditional categories. The question for the court was whether any "introduction of a new customs duty or any increase in an existing duty is automatically without effect or is absolutely void." 24 This approach, if an affirmative answer were given, would involve the startling proposition that a customs and excise tribunal, set up under a statute to ensure that the customs and excise correctly applied the tariff, also had jurisdiction by virtue of some implied rule of community Law to declare either an international treaty, the Benelux protocol, or the law ratifying that Treaty in the Netherlands at least in part "absolutely void".

For the German Government which also intervened the matter was simple. The obligation to pay customs duties did not at that stage derive from EEC Law but from municipal law. Article 12 laid down a duty on each State which was owed to other Member States. Individual taxpayers only derived rights and duties under community law from regulations laid down by the Community institutions.

In its judgment the European Court in the first place held that "Community law had an authority which could be invoked by their nationals, before courts and tribunals." In other words it had an "internal effect", to use the Dutch phrase, and was "directly applicable". On the question of the direct effect of the provision a taxpayer was entitled "to plead infringements of the obligations" before a national court. It was an additional "guarantee" against an infringement of article 12 . What article 12 did was to provide "direct legal protection" of the individual rights of their nationals. It gave an individual the right to prevent "the implementation of a national decision taken contrary to the provisions of the Treaty." Elsewhere in the judgment the court stated that the Treaty "conferred upon [individuals] rights which become part of their legal heritage.",25 
The court thus used rather general language in its explanation of the "direct effect" of article 12. It left it to each national system to supply a name to this private right or to place it in the appropriate category under national law. But the Court did indicate the essential characteristic of the right. It was a right as opposed to a public interest; a private right that the taxpayer could choose to use or not; it was designed to be a "guarantee" of Treaty observance; the national court had to give "direct legal protection to the right" so that the guarantee remained intact; it had to be "effective".

For the solution of the instant case the court's judgment was an adequate ruling for the national judge. Since the customs and excise tribunal had become involved before any damage had occurred as a result of the Netherlands breach of its obligations, all that the tribunal had to do was to prevent "implementation" of the national decision taken contrary to the provisions of the Treaty; in other words to annul the decision of the customs authority imposing a tax of $8 \%$ ad valorem. The problem would then be shifted to the tax authority to decide what it could lawfully do. It could not presumably issue a new customs assessment imposing a 3\% duty on the product because that rate no longer lawfully existed: it had been lawfully abolished by an international treaty, the Benelux protocol, ratified by an Act of the Netherlands Parliament. If it did issue a decision taxing the product at $3 \%$ that decision could not be challenged under community law but could presumably be attacked under national law in that $3 \%$ was not the lawful duty under tariff heading 39.01-a-1 of the Benelux tariff. Neither the national court nor the taxpayer needed to consider further under what category of domestic right the community right fell. That was a problem left to the customs and excise.

The immediate explanation for the private right that the European Court had found implicit in article 12 of the Treaty was that it was a right to be treated as if the infringement had not occurred, i.e. a right to be put back into the position that the importer would have been in if the Netherlands had not infringed the Treaty. Whether this would have authorized the national court or the customs and excise to reduce the liability to $3 \%$ rather than simply quash it in its entirety was and remains unclear. Put in terms more familiar to the common law world there would thus be two distinct obligations contained in article 12: an express duty owed to other Member States not to enact laws which increased duties and a second, implied duty owed to taxpayers not to tax them at a higher rate than the rate applicable on the date the Treaty entered into force. The breach of the former duty would be sanctioned by a default action under article 169 ; the latter by a private action in the national court. The distinction between the two duties is well illustrated by a number of cases. ${ }^{26}$ In one case, for example, in a default action the Commission had obtained a declaration that France's advertising code for alcohols infringed article 30 of the Treaty. ${ }^{25}$ When a number of producers and importers of 
alcohols were subsequently prosecuted for infringement of the code they alleged that the particular provisions of the code declared incompatible with the Treaty could not be applied to them. On a reference to the European Court the court held that only certain of the defendants could lay claim to individual rights under the Treaty, namely those who had imported goods from other Member States. The legislation itself was not void. Although all defendants were charged under the same provision of the code the code only infringed the private rights of some of them. It was not the enforceability of the code that was in issue but the enforceability of a private right.

Conversely it is conceivable that a State may break a duty owed to an individual trader without at the same time breaking its duty to other Member States and the Community Institutions. In Commission v. Italy ${ }^{27}$ Italy was alleged to have defaulted in its obligations under a Council regulation by failing to pay export refunds promptly. The regulations laid down a complete system for the payment of refunds with no or almost no powers reserved to the member State save to execute the regulation. The State did have to get the necessary funds voted by Parliament for although the ultimate bill would be borne by the community the Italian ministry had to have cash in hand. Italy alleged that if there was delay in payment of sums due to an importer that was the fault or responsibility of the officials concerned. An exporter who was aggrieved by such a delay could sue in the Italian courts for payment and damages ["sole responsibility of the official who is liable under national law"] but there was no breach of a duty owed to the community by the member state itself which had not taken any measures that conflicted with community Law.

The Court held that "the existence of remedies available through the national courts cannot in any way prejudice the making of the application referred to in Article 169 since the two procedures have different objectives and effects."28

The object of the action under article 169 is to review the conduct of the Member State. The object of the action in the national court is to redress the grievance of an individual, usually a trading company. Neither the one nor the other, however, has the object or effect of annulment of national legislation. It is in all cases for the competent national authority, the legislature, or the executive or, in some constitutions, the constitutional court to annul or rescind the offending norm. ${ }^{29}$

This was the point of the distinction demonstrated in the second Simmenthal case ${ }^{30}$ betwen the competence of the lower court and the competence of the Italian Constitutional Court. The Italian Constitutional Court had recognized the supremacy of community law over state law. At that time it also maintained the

27. Commission v. Ilaly [1970] E.C.R. 25.

28. Ibid.

29. Waterkeyn Case [1982] E.C.R. 4337.

30. Amministrazione Delle Finanze Dello Stato v. Simmenthal [1978] E.C.R. 629. 
principle that a lower court was obliged under the Italian constitution to give full effect to national law unless and until the constitutional court had declared the Italian statute void for breach of community law. ${ }^{31}$ The first instance judge in effect asked the European Court to rule whether he should follow the judgments of the Constitutional Court and refer the constitutionality of an Italian law, which had entered into force after the EEC Treaty, to the Constitutional Court even though the European Court, in the first Simmenthal case, ${ }^{32}$ had held the veterinary inspections and the charges for such inspections were incompatible with the Treaty and the object of the case was simply the repayment of the fees illegally charged.

The Italian Government, in its argument before the European Court urged the European Court to rethink the doctrine of direct effect. "If the national court is acknowledged to have the power not to apply a national law which is incompatible with the community law that is tantamount to guaranteeing the application of the community legal rule only in the case actually before the court and protecting the specific right claimed in that case; but the national provision remains in force and is in fact exclusively applicable if there has not been a submission to the court that there may have been a breach of the rights conferred upon individuals by community rules." 33

In the Italian Government's view the solution adopted by the constitutional court consisting in what might be compared with a certiorari to quash the offending legislation would be clearly more effective and significant than the "private rights" analysis adopted by the European Court. There was no conflict with the essential objective of the EEC Treaty since the national court would not apply or give effect to a national law which was incompatible with Treaty; it would simply adjourn pending the repeal of the offending legislation or the declaration of the offending legislation's unconstitutionality by the Constitutional Court. Such a declaration would remove the legislation $a b$ initio so that, in the instant case the importer would get its money back.

In its judgment the European Court held that every national court, in a case within its jurisdiction, had to apply community law in its entirety and protect rights which the latter conferred on individuals: "A national court which is called upon, within the limits of its jurisdiction, to apply provisions of community law is under a duty to give full effect to those provisions, if necessary refusing of its own motion to apply any conflicting provision of national legislation, even if adopted subsequently, and it is not necessary for the court to request or await the prior setting aside of such provisions by legislative or other constitutional means."34

31. Judgment no. 183, 27 December 1973, Corte Constitutionale; Judgment no. 232, 30 October 1975, Corte Constitutionale; Judgment no. 205, 28 July 1976, Corte Constitutionale; Judgment no. 206, 28 July 1976, Corte Constitutionale.

32. Amministrazione v. Simmenthal [1976] E.C.R. 1871.

33. Emphasis added.

34. [1978] E.C.R. 629, at p.644. 
The court thus made a distinction between the private law remedy - the enforcement of a community right - in preference to the public law "remedy" of quashing or setting aside the offending national law. Not every remedy under national law is therefore, as a matter of community law, appropriate to uphold community rights.

The cases based upon article 95 and in particular the restitution cases show both the national court and the European Court struggling to mesh together the right with the remedy into a coherent doctrine of direct effect.

In Molkerei-Zentrale Westfalen v. Hauptzollamt Paderborm ${ }^{35}$ a dispute that had been going on for a number of years reached the Bundesfinanzhof. Germany apparently imposed a tax on imported milk powder whereas neither domestic milk powder nor whole milk was subject to tax. In an earlier case ${ }^{36}$ the European Court had held that article 95 and possibly even article 97 were capable of conferring right on individuals which national courts were obliged to protect. The Bundesfinanzhof in the present case asked the court to look again at the issue. In its judgement the Bundesfinanzhof pointed out that under the doctrine "the national court must place this individual in the same position as if the State in question had already fulfilled its obligations."

The Bundesfinanzhof pointed out that a tax court was being asked "to anticipate, by thousands of separate decisions, the action of the legislature ... or to make good its failure to act." This was beyond the powers of a tax court.

For the Commission it was argued that "It may happen that individuals can have themselves placed in the same position as if national law had already been amended, whereas the sole result which the Commission or the other Member States may bring about is that the State which is found to have failed to fulfil its obligations shall take the necessary measures to comply with the judgment of the Court of Justice."

In its judgment the court stressed that "the complexity of given situations in a State cannot alter the legal nature of a directly applicable Community provision, especially as the Community rule must be applied with the same force in all Member States." It should be noted that the Court does not mention uniformity of interpretation but uniformity of legal force. "Furthermore," as the Court said, "Article 95 does not restrict the powers of the national courts to apply, from among the various procedures available under national law, those which are appropriate for the purpose of protecting individual rights conferred by community law. In particular when internal taxation is incompatible with the first paragraph of article 95 only beyond a certain amount, it is for the national court to decide, according to the rules of its national law, whether this illegality affects the taxation as a whole or only so much of it as exceeds that amount."

The origin of the dispute was not a claim to damages but an objection to the payment of the tax. As in Van Gend en Loos it was an action to quash the tax

36. Lutticke v. Hauptzollamt Saarlouis [1966] E.C.R. 205. 
assessment. However in the court's judgement it appears to accept the "as if" type analysis. $^{37}$

What the court was stressing in its judgment was that the national court had to remove the protective margin. So long as the taxpayer was treated by the court as if the obligation had not been broken how that was achieved was a matter for the national court.

In Hans 7 ust v. Danish Ministry for Fiscal Affairs ${ }^{38}$ the plaintiff taxpayer was a producer and importer of wines and spirits in Denmark. It was liable to pay excise duties to the Danish treasury on its total sales of spirits. It argued, in a test case, that during the month of June 1978 it had overpaid excise duties. It had paid the tax under protest claiming that the rate of tax was incompatible with article 95 of the EEC Treaty. It sought repayment of that sum and reserved the right to claim all the tax it had overpaid between the date Denmark joined the community and the date of the action. The Danish court asked for a ruling on a number of points including whether article 95 could be relied upon by Danish producers or only by importers. Additionally, in question 4 the Danish court asked if community law contained "any rules of significance for deciding the question of the repayment of taxes, payment of which was contrary to article 95 ?" Was it of any relevance that "a trader can establish that he has suffered loss"?

In its arguments before the court for the first time the tortious ideas behind the doctrine of direct effect began to emerge. The plaintiff claimed that the increase in the tax on imported spirits had resulted "not only in a serious reduction in the profits of Hans Just but also compelled it to reduce staff." Under Danish law, however, it appears that monies paid over as a result of a mistake of law were not recoverable. The taxpayer in effect argued that the court should recognise that the doctrine of direct effect either created a community right to restitution or a community right to damages which national law could not lawfully abridge.

The court founded the duty of national courts to find the appropriate remedy, not on the doctrine of direct effect alone, but on the duty of co-operation in article 5 of the Treaty. That article provides that Member States shall take all appropriate measures ... whether general or particular to ensure fulfilment of the obligations arising out of this Treaty." The European Court has stressed that the national courts are the Member States as regard judicial remedies. Although article 5 is not in itself "directly effective" it is, when coupled with the right conferring provision; community rights therefore are only in part implied. The fourth question of the Danish judge was therefore a question as to whether the remedies available under Danish law - whether the category into which the right should fall - were "appropriate measures" within the meaning of article 5 of the Treaty. The court answered that:

37. The expression "does not restrict the powers of the national court" is specifically an answer to the Bundefinanzhof's assertion that a tax court could only quash an assessment rather than alter or amend an assessment.

38. [1980] E.C.R. 501 , 
"in the absence of community rules concerning the refunding of national charges which had been unlawfully levied, it is for the domestic legal system of each Member State to designate the courts having jurisdiction and to determine the procedural conditions governing actions at law intended to ensure the protection of the rights which subjects derive from the direct effect of community law, it being understood that such conditions cannot be less favourable than those relating to similiar actions of a domestic nature and that under no circumstances may they be so adapted as to make it impossible in practice to exercise the rights which the national courts are bound to protect."

"The protection of rights guaranteed in the matter by community law does not require an order for the recovery of charges improperly made to be granted in conditions which would involve the unjust enrichment of those entitled."

The court went on to say that there was nothing in community law to prevent a national court from taking into account "the damage which an importer may have suffered because the effect of the discriminatory or protective tax provisions was to restrict the volume of imports from other Member States." 39

At first sight this looks as though the European Court is merely saying that the national legal system can provide whatever remedies it considers appropriate. The categorization of the community right as a right to compensation is a matter solely for national law to determine. The important point in the development of the concept of direct effect appears to be the recognition that a claim to damages may be an "appropriate measure" within the meaning of article 5 of the Treaty, the "normal" remedy, according to both the Advocate-General and the court being the restitution of the overpaid taxes.

"Proof of damage or impoverishment as a precondition for bringing proceedings is known in the legal systems of all the Member States and in the community legal system itself as an expression of the general principle of natural justice."40

It is evident that in the eyes of the court and the Advocate-General both damages in tort and repayment of sums overpaid were conceptually based on the same principle of unjust impoverishment and were the natural consequences of a community right's infringement.

A slight shift in emphasis away from mere reference to national remedies was seen in Amministrazione delle. Finanze dello Stato v. San Giorgio Spa, ${ }^{41}$ which concerned the perennial problem of Italian frontier inspection charges. The Italian Constitutional Court had declared a law invalid as incompatible with EEC Law. On the basis of that decision ${ }^{42}$ the plaintiff brought an action for the recovery of sums which it had been obliged to pay between 1974 and 1977 as health inspection

39. Ibid, at p.523.

40. Ibid, at p.532

41. [1983] E.C.R. 3595.

42. No. 163, Corte Constitutionale, 19 December 1977. 
charges. After the action had started, the Government issued a new Decree which expressly provided that certain taxes on goods which had been overpaid could not be recovered when the taxpayer had passed the tax on in any way whatsoever to its customers. There was a presumption of passing on if the property in the taxed goods had been transferred and there was a further presumption that the property had been so transferred.

This was a rather ingenious attempt to mitigate the consequences of a number of European Court rulings declaring numerous Italian indirect taxes incompatible with the Treaty.

In his opinion Mancini, Advocate-General, explained the rationale for excluding recourse to the idea of passing-on save in exceptional circumstances:

"How is it possible to prevent the Member States - in the certainty that they will not have to refund the amounts unduly levied - from continuing to levy charges having an effect equivalent to customs duties notwithstanding the community prohibitions? Who could prevent them from so doing if entrepreneurs were deprived of any judicial means of stopping such a practice ..."

The Court held that "the repayment of charges levied by a Member State contrary to community law is a consequence of and an adjunct to, the rights conferred on individuals by the Community provisions prohibiting the charges." It added that " . . . the requirement of non discrimination laid down by the court cannot be construed as justifying legislative measures intended to render any repayment of charges levied contrary to community law virtually impossible, even if the same treatment is extended to taxpayers who have similar claims arising from an infringement of national tax law."

Once again both the Court and the Advocate-General saw repayment of the overpaid taxes as the natural consequence of breach of a community right. It may however be questioned whether repayment really is the appropriate remedy, at least in the case of article 95 . For example, should an importer of wine into the United Kingdom reclaim excise overpaid in relation to beer contrary to article $95 ?^{43}$ That claim should as a matter of "natural justice" be denied on the basis that the tax has been passed on and, since many wine importers in the United Kingdom are part of brewing and retail conglomerates, the importers may well have enjoyed the profit from increased beer sales. If such an importer were to recover the overpaid tax, retain the benefit of the increased sales of beer and enjoy the services provided by the State but paid for by the product of the tax, there would, by any standards, be an unjust enrichment. Those who have suffered by reason of the discriminatory tax are the wine producers in the regions that would typically supply the British market. It is to them that a remedy, if at all, should be given. It is they who were intended to benefit from article 95 . As regards frontier charges most have concerned trivial sums of money. As the court has pointed out, the main effect of frontier charges is to delay goods at the frontier for which compensation

43. Commission v. United Kingdom [1983] E.C.R. 2315. 
might well be a more appropriate remedy instead of or in addition to restitution. It has been suggested ${ }^{44}$ that the solution to the problem of unjust enrichment is for a state to introduce an extremely short period of limitation for bringing a restitution action. If such a period applied to similar claims against the government under domestic law no criticism could be made under EEC Law. It may, however, be questioned whether short periods of limitation would not in fact act as an arbitrary filter to justified claims and an arbitrary discrimination against aggrieved persons in other Member States. ${ }^{45}$

There are a number of cases in which the claims in the national court have been unambiguously based on a claim in damages of which the most notable is Defrenne v. Sabena. ${ }^{46}$ A Belgian Royal Decree of 1967 , intended to implement the equal pay principle in Article 119, had simply provided a right of action to women to receive equal pay: "any woman worker may institute proceedings before the relevant court for the application of the principle that men and women should receive equal pay for equal work."

In March 1968 the plaintiff instituted proceedings before the Tribunal de Travail - the industrial tribunal - claiming damages for the injury she had suffered between 15 February 1963 and 1 February 1966 by being paid less than a male steward. The reason why her claim stretched back only to 15 February 1963 was that before that date her claim was statute barred under municipal law. On 1 February 1966 at the other end Sabena had unilaterally decided to pay stewards and stewardesses at the same rate.

It is not immediately clear from the report of the case exactly what the legal form of Miss Defrenne's claim was despite the reference to the Royal Decree. This was in part due to the somewhat strange phenomenon that Belgium declined to present observations to the court and Sabena only appeared at the oral hearing. That the claim was based exclusively on the direct effect of article 119 seems clear. None of the parties who intervened discussed the issue of the remedy. It seems probable, however, that the remedy was tortious in nature (i.e. damages for an injury) rather than contractual (that her contract had been altered by article 119) or restitutionary (that Sabena had enjoyed an unjust enrichment). Clearly Defrenne was not seeking annulment or review of her contract but compensation amounting to arrears of pay. She was inevitably, if not expressly, arguing that article 119 of the Treaty imposed a duty on Sabena from 1962 onwards not to discriminate against her, a breach of that duty by Sabena and damages. Not surprisingly the judgment of the court concentrates on the right conferred by the community on the woman to the exclusion of the rather more dubious aspect of a duty imposed on Sabena. The right is conferred "on any individual who has an interest in the performance

44. Mancini, Advocate-General in the San Giorgio case [1983] E.C.R. at p.3632.

45. See T. C. Hartley, "The effect in national law of judgments of the European Court", [1980] E. $L$. Rev. 3666.

46. [1976] E.C.R. 455. 
of the duties thus laid down." Although the duty is expressly imposed on Member States [no. 32] there appears to be an implied duty imposed on employers. In the course of the judgment the court expressly recognized that "In view of the large number of people concerned such claims, which undertakings could not have foreseen, might seriously affect the financial situation of such undertakings and even drive some of them to bankruptcy." The companies had been led "to continue with practices which were contrary to article 119 , although not yet prohibited under their national law." The direct effect, as an exceptional matter, could not be relied on as regards the past except as regards workers who had "already brought legal proceedings or made an equivalent claim."

It appears, therefore, that Sabena was subject to a duty which, the court concedes, could not have been foreseen. It was liable for practices contrary to article $\mathbf{1 1 9}$ for which it would normally be liable in damages to any person "who has an interest in the performance of the duty."

There is no doubt that in the view of the court the direct effect of article 119 as a matter of community law gave rise to a claim in damages from the moment the breach occurred. It was only on the grounds of legal certainty that the court suspended any claims for the past. But the mere existence of the power of the court to limit the consequences of a breach of article 119 for the past would seem to confirm that the claim to money was directly conferred by community law. The European Court could hardly have suspended the operation of a purely national remedy.

The duty in the case of articles 119,13 and 95 is a duty to pay and a duty not to tax respectively. The problem of damages becomes central and unavoidable when the question is as to the effect of the breach of a provision which requires a state to do something or to refrain from doing something other than paying or taxing. For example, if a state prevents the import of a product or destroys a consignment of a product for spurious health reasons, contrary to article 30 of the Treaty, the judicial review of the ban or the destruction will be of limited comfort to the importer who may have lost a great deal of money or even have been bankrupted while the ban lasted. In those States in which no interim relief is available against the government it might well be some time before a ban is lifted, even if the aggrieved trader acted with all possible speed. If, for example, a state, in breach of community law, subsidizes an exporter so that that exporter manages to drive a competitor off the market, a judicial review of the decision to subsidize, even supposing it were practicable, would not "guarantee" that Community law was complied with.

In Salgoil v. Italy ${ }^{47}$ an Italian company had been refused a licence to import fullers earth into Italy from another Member State of the EEC. Assuming that the refusal of an import licence was wrongful the normal remedy under Italian law 
would have been an action in the administrative court, in effect for a judicial review of the decision. It seems that in an administrative court in Italy, as in judicial review proceedings in England, the applicant relies on a legitimate interest rather than a right, stricto sensu, which must be balanced against the public interests of the State. Instead of seeking a public law remedy the plaintiff started civil proceedings for damages to compensate it for the loss it had suffered by being forced to break its contract with its suppliers. The court at first instance declined jurisdiction on the grounds that it was a public law matter: no right of Salgoil had been infringed but rather a legitimate interest that ought to have been defended in the administrative courts. Salgoil appealed to the Corte d'Appello which on this issue of jurisdiction referred a rather long and complicated question to the European Court designed to discover the true classification under domestic law of an enforceable community right. In its reply the European Court appeared to stress that it was an absolute right that was conferred by community law requiring direct and immediate protection by the national court without reference to the public interest of the State. It went on to say that "It is for the legal system of each Member State to decide which court has jurisdiction and, for this purpose to classify those rights with reference to the criteria of national law." 48 The European Court was not prepared to get involved in national jurisdiction between the civil courts and the administrative courts in particular as the division between jurisdictions varies from system to system, ranging from the complete separation of France with parallel remedies in both systems to the distinction based on remedies of Italy and to some extent the United Kingdom. This judgment does not mean however that the extent of the remedy granted for breach of a community right is a matter for each State to determine free of Community interference; there must be direct and immediate protection of the rights. It is nevertheless striking that in the Salgoil case the court seemed to retreat from its earlier stress on the private, subjective nature, of the right which entered the "legal heritage" of the individual concerned.

In Russo v. AIMA the court examined-more closely a claim based on damages for breach of community law. ${ }^{49}$ In 1973 the world price of a range of community agricultural commodities went above the EEC target price resulting in a shortage and a domestic price rise. In order to subsidize consumers the Italian government purchased durum wheat on the world market and sold it on the domestic market below cost but nevertheless around the target price. This had the effect of bringing the domestic price down to just above the target price. An Italian producer of wheat claimed damages against the branch of the Ministry of Agriculture concerned representing the difference between the price that he had received for his wheat and the price he would have received had the Italian State not carried out its operation.

On a reference to the European Court as to whether the producer was entitled to damages in such a situation and whether the producer should obtain complete

48. Emphasis supplied.

49. Russo v. A.I.M.A. [1976] E.C.R. 45. 
compensation, the Commission argued that not every breach of community law gave rise to a claim in damages: "a right to damages should arise only to the extent that a provision of community law was intended to protect the particular interests of individuals ... Any other solution would involve a serious risk of differences in the application and scope of community law depending on the legal system within which it is invoked." 50

With regard to the extent of protection, i.e. whether there was any damage and whether it was compensable in money and the extent to which it should be compensated, that was a matter for national law to determine in accordance with the principles of appropriateness and effectiveness.

The Advocate-General, Mr Reischl, was even more clear:

"there is a principle of community law according to which the authorities and in particular the courts of Member States are under a duty to safeguard the interests of individuals affected by any breach of community law, which establish individual rights, by giving these persons direct and immediate protection ... In such circumstances when the other prerequisites under the particular national law are present, a claim for damages may lie against the Member State which has not fulfilled its obligations under the Treaty ... The liability of a Member State for the consequences flowing from an infringement of community law also arises out of the obligation to provide effective protection of these rights provided that the other prerequisites under national law are present." $" 51$

The court held that under community rules, "an individual may claim that he should not be prevented from obtaining a price approximating to the target price and in any event not lower than the intervention price." An individual farmer may not claim that he has suffered damage under community law if the price which he has actually obtained on the market exceeds the target price." The court concluded: "If an individual producer has suffered damage as a result of the intervention of a Member State in violation of community law it will be for the State, as regards the injured party, to take the consequences upon itself in the context of the provisions of national law relating to the liability of the state."

When the court refers to "the context of the provisions of national law on the liability of the State" it is not thereby authorizing a system of national law to deny all liability of the State but rather placing the community right in the context of such liability. It is perfectly conceivable that the State breaks its obligations under community law without causing any loss to an individual recognisable under community law. Indeed such appears to have been the case here. Community law

50. The Commision was inviting the Court to consider the doctrine of direct effect as being the same doctrine as that under which claims to damages against the community were brought under article 215 of the Treaty. Cf. the assimilation of these two doctrines in Bourgoin by the majority of the Court of Appeal but for a rather different purpose.

51. [1976] E.C.R., at p.62. 
did not guarantee a particular level of profit but merely that the producer would obtain at least the intervention price. Since the producer here had managed to obtain a price above the target price there had been no breach of the producers rights under community law. If the Italian State had caused the market price to fall below the target price, or conceivably only below the intervention price, the producer would have been entitled to damages provided he could prove the casual link.

In other words the Court, as a matter of community law establishes the extent of the right guaranteed under community law. Damages are available only to the extent that the community guarantee has been infringed within the context of state liability.

Some support for the argument that State law can exclude a claim for compensation against the State for breach of a community provision causing damage to an individual is found in the judgment of the European Court in the first of the "butter-buying cruises" cases. ${ }^{52}$ This case concerned the unlawful exemption from taxes and agricultural levies granted to passengers on such butter cruises. The actual object of the litigation was, in effect, for an order to force the German Customs and Excise to tax the passengers by a review of their exemption decision.

In common law terms it was a public law type remedy that was sought rather than a claim for compensation for the loss caused by the illegal decision. One of the points that arose was as to the standing of the plaintiff grocery chain to bring the action. The grocery chain based their interest in bringing the proceedings on the trade that they alleged they had lost through the diversion of trade to the butter-buying cruises. At one time over 8,000 tonnes of such butter was sold annually on butter-buying cruises, a proportion of which must have been diverted from the plaintiff's shops. One question that arose was whether the various community provisions allegedly broken conferred rights on such a third party. There was no doubt that the regulations, directives and the Treaty conferred rights on taxpayers against the customs and excise. It was less clear that they conferred rights on those who had suffered purely economic loss through the misapplication of community rules.

According to the United Kingdom which submitted observations to the court solely on this issue the plaintiff in the present case was usurping the role of the Commission. It was seeking a remedy by private action to compel a Member State to remedy its default generally, since no right had been directly conferred on the grocery chain by community law. Whether it had any right to seek a judicial review or obtain some order or declaratory relief in these circumstances depended solely on national law.

Capotorti, Advocate-General, in a very clear analysis of legal rules, stressed that the case did not concern damages but a public law remedy. He drew a distinction 
between a legal rule, a personal right and an interest in the application of the rule. A rule dealing with taxation on importation conferred personal rights on an importer and duties on the customs and excise. Importers as a "class" might have an interest but no right until an individual transaction had taken place. This case raised the issue of whether other traders had an interest in the proper application of community law. No question of a right arose. The persons on whom rights were conferred by community law were a sufficiently defined class. Those who might have an interest in the correct application of law were much more numerous.

He rejected entirely the proposition that the doctrine of direct effect had created some kind of popular action so that anyone with an interest in the correct application of community law could seek a review of the application of community law by the State. But he went on to point out that if a person had a sufficient interest under domestic law to ask for judicial review there was nothing to stop his invoking community rules and thus indirectly ensuring that community law was complied with.

The Court appears to have followed the Advocate-General's approach:

"With regard to an action to compel ... [the customs and excise] ... to comply with obligations arising from community rules in a given legal situation in which that trader is not involved but is economically adversely affected by the failure to observe community law ... [community law] was not intended to create new remedies in the national courts to ensure the observance of community law other than those already laid down by national law. On the other hand the system of legal protection established by the Treaty, as set out in Article 177 in particular, implies that it must be possible for every type of action provided for by national law to be available for the purpose of ensuring observance of community provisions having direct effect, on the same conditions concerning the admissibility and procedure as would apply were it a question of ensuring observance of national law."

If, therefore, the grocery chain had sufficient interest under German law to challenge a decision addressed to another taxpayer on the grounds of breach of German law, it would similarly have standing where the allegation was breach of community law. Read in its context, therefore, nothing in the Rewpe case supports the proposition, advanced by the majority in the Court of Appeal in Bourgoin that community law leaves a Member State free to decide on its own liability in its own courts for breach of community law when faced with a claim by an individual whose rights as opposed to interests (or "public rights" as they are now rather inaptly called) have been affected.

Once the distinction outlined by Capotorti, Advocate-General, is understood the true reason for the court's refusal to interpret article 95 in the reference from the Milan Court in Foglia v. Novello ${ }^{53}$ becomes apparent. In that case a wine

53. [1980] E.C.R. 745 (No.1) and more significantly Foglia v. Novello (No.2) [1981] E.C.R. 3045, at p.3065, nos. 5,28 and 29 . 
merchant sued one of its customers for breach of contract. Article 95 conferred no rights on a customer in a transaction with a wine merchant and therefore no question of national law supplying a remedy for breach of a community provision arose. As a matter of community law, article 95 conferred a right on a taxpayer against the relevant national taxation authority. It did not, and could not, as a matter of community law be relevant to the interpretation or application of an Italian contract involving two Italian subjects where not even a recognizable interest in the application of community law could be discerned.

An interesting use of a claim for damages for a community wrong suffered by an EEC subject at the hands of the State occured in Pecastaing v. Belgium..$^{54}$ In that case a French woman was refused a residence permit by the competent authority in Belgium. Instead of seeking to quash this decision in the administrative court (there was some doubt whether such a remedy was available in the circumstances of this case) she began an action by writ for damages to compensate her for the loss she had suffered arising from an improper administrative measure. At the same time she sought interlocutory relief in the form of a stay of execution of the decision that she leave the country. The case referred to the European Court raised the issue of whether such interlocutory relief had to be available under directive $64 / 221$ and no question was raised as to whether the infringement of her community right to reside in Belgium was a wrong giving rise to a cause of action in damages. Indeed, the plaintiff was primarily concerned to get the decision suspended and in effect reviewed by the civil courts, rather than to vindicate a claim in damages. Furthermore she argued that Member States "cannot have a choice between observing the law and paying damages by way of reparation for breach thereof. The State should be obliged to observe the rule of law."

In most cases where an EEC national is refused leave to enter or is deported contrary to EEC law his prime concern will be to have the decision quashed so that a claim to damages would be merely ancillary. It is however possible to imagine the converse situation where the wrongful measure causes the loss of a job or contract without any particular interest in the aggrieved persons having the measure judicially reviewed; his interest is in compensation. To deny a State's obligation to compensate would, in these rare cases, not provide the subject of community law with an appropriate and effective remedy which will put him into the position he would have been in, if his right had not been infringed.

\section{Conclusion}

The European Court has reiterated the national court's duty to protect fully and immediately rights granted by community law. The essential ingredients of the community right have been gradually elucidated by the European Court. It is a private right which belongs to the beneficiary, a right to be treated as if the Treaty or subordinate community legislation had not been broken. That is the result to be 
achieved by the national court which nevertheless to some extent has a choice of form and methods. Although procedure and forum must vary from system to system, article 5 of the Treaty places a duty directly on courts to take all appropriate measures to ensure fulfilment of the obligations arising out of the EEC Treaty and subordinate legislation. Although it is up to each national system to categorize a community right, to place it in its national context, this does not mean that the binding force of the right derives from national law or the national statute which transferred powers to the Community. It is a gradual process of recognition on the part of both the European Court and the National Court of what type of right is involved. Although there is frequent reference in the judgments of the European Court to the analogous enforcement of rights under National Law against the State, they are only imperfect analogies since both a State and a Community citizen are equally subjects of community law. The peculiarities that derive from the relationship of sovereign and subject are not necessarily appropriate in this changed situation. In common law terms, it is a wrong for a State to infringe private rights for which the State is liable by analogy with the cause of action arising out of a breach of a public duty under a statute for which the Crown also owes a duty to individual subjects. If liability should ultimately need to be restricted on the basis that the doctrine of direct effect involves too great a liability for the state exchequer, it is then that community-wide legislation might need to be enacted for the same reasons which led the court to suspend the operation of article 119 in Defrenne v. Sabena. It is not for national law to abridge community rights, though to some extent this is a consequence or side effect of its general power to regulate judicial procedure which still remains a purely State power. 